\title{
Issues of Emerging Markets in India with reference to Menswear
}

\author{
Vandana Narang ${ }^{1}$, Noopur Anand ${ }^{2}$ \\ ${ }^{1}$ (Fashion Design Department, National Institute of Fashion Technology, India) \\ ${ }^{2}$ (Fashion Technology Department, National Institute of Fashion Technology, India)
}

\begin{abstract}
The emerging markets of India are the new platforms for apparel and fashion brands and for designers that provide growing opportunities for business in the country. These markets in India's Tier 2 and 3 towns and rural areas are the new consumption centers. Their apparent newness also renders them as uncertain markets. This paper explores and identifies factors that can be the differentiators for fashion and apparel for menswear in these emerging markets.
\end{abstract}

Keywords: Uncertain market conditions, emerging markets, Fashion and Apparel, Menswear, design, trends.

\section{INTRODUCTION}

Fashion is all about uncertainty. It thrives on the $\mathrm{X}$-factor. Uncertainty and ambiguity makes designing clothes for these emerging markets more challenging and exciting, as there is no precedent for reference. Fashion's cyclical nature makes it fickle, yet at the same time, identity defining. Men are considered a conservative gender by fashionistas and this is more so in India. They prefer sticking to the 'acceptable idea' as opposed to looking different. Women on the other hand would be mortified if they looked similar to another in the group. But today there is a small set in the younger age group that would rather 'stand out' in the crowd. Designing for menswear needs a study of various influences and has to be done in a historical context (Hopkins ${ }^{1}, 2011$ ).

"Men's fashion is something of an enigma at times.... it seems simple - just don pants, a button down shirt....... and the look is ready." (Moroz $\left.{ }^{2}, 2008\right)$. Historically, men are considered to be tolerant of shopping for clothes and their interest are more in other pursuits like technical gizmos rather than for apparel. Piers Wehner ${ }^{3}$ in his article "Its Reigning Men" in The Estate Gazette (2008) said that despite what might be generally understood the menswear market is sizeable. The sector in UK is worth $£ 9$ billion and it grew by 3.3 percent in year 2007-08. In the same article he also remarked that men's attitudes are changing towards clothing; metro sexuality, magazines and style icons like David Beckham are encouraging men to groom themselves.

Menswear fashion today is the fastest growing segment. Europe's leading fast fashion retailers are stepping up their effort to "court" an expanding market of male consumers with an increasing "appetite for the trends at affordable prices" (Marsh $\left.{ }^{4}, 2008\right)$. The myths surrounding men's fashion are that there is no men's fashion and men dress for fit and comfort, rather than for style. It is also believed that women select clothes for men, who do not observe clothes. The societal notion that men who dress up are peculiar in one way or another persists along with the belief that most men do not pursue endless seasonal fads (Carick $\left.{ }^{5}, 1994\right)$.

This paper focuses on the menswear market in India and the upsurge in the demand for fashion products in the menswear category primarily coming from the emerging markets. The paper identifies the factors that are important while designing for these markets in the menswear category. Over the last decade, a trend towards individuality has taken root in society. This personal image influences how individuals feel about themselves; how they react to others..... what consumers define as a good fit in apparel.

\section{MEN AS CONSUMERS}

Men's attitude towards clothing is changing; the demand for a greater variety in men's clothing ranges has risen in conjunction with the surge in male grooming and healthcare sectors (Wehner ${ }^{3}, 2008$ ). Patrick Tucker $^{6}$ has stated in Smart Fashion "no industry is more fickle than fashion. Whether we're wearing a grass skirt or $\$ 500$ blue jeans, we like a bit of protection from the elements, a feeling of warmth and security, and to make an impression". Clothes that we wear reflect our personalities, our character and help to make our image (Anderson $\left.{ }^{7}, 1999\right)$.

Historically, the men's apparel market in India has been significantly larger than women's apparel market (Talukdar $\left.{ }^{8}, 2011\right)$. India's apparel market is in the throes of change (Vasudev' ${ }^{9}$ 2010). Rapid growth and rising urbanization have spawned a new class of consumers with more money to spend and a growing passion for fashion. As men's taste grows more sophisticated they are providing a new avenue for much needed growth in the industry. At one time, the Indian market for menswear comprised primarily of three basic categories: casual, working clothes and occasion wear. However, with new interests and a broader range of activities and 
with an increased demand for clothing, men are spending more on clothing and are embracing the idea of fashion as a form of self expression rather than merely as a functional purchase (Talukdar ${ }^{8}$, 2011). Exclusive men's fashion week was launched in London in 1998 (Bakewell ${ }^{10}$ et al, 2006) and India men's fashion week in 2009. Leading international retailers including H\&M, Top man, Mango and New Look have opened exclusive men's only stores.

\section{EMERGING MARKETS}

Uncertainty presents opportunities for firms/ business. Placing/ using uncertainty as a primary driver, prepares the organization for, and helps it, to adapt to the unknown. This helps the organization explore possibilities and benefit, thus making the unknown and the uncertain as an opportunity. Substantial improvements can be made to the way we manage innovation by actively embracing uncertainty, rather than working around or ignoring it.

India is seeing its Tier 2 and Tier 3 towns and its rural landscape emerging as new consumption centers. Some of the drivers that may have contributed to this change are -

1. Ecological connectivity - Infrastructural improvements in terms of new roads especially the expressways connecting villages and cities provided a spurt to growth to these new townships. Some of them were tiny obscure villages at one time, which with increased traffic have seen the development in reality sector. The expansion of markets and building of malls in some places, roadside eating joints give a boost to the local economy and a platform for generation of income. These are the new portals that provide exposure to the local population leading to a surge in demand even for products that these customers may not be familiar with or even be in need of. Connectivity in terms of the net and television have also provided platforms for information exchange, exposure to the alternative ways of life and living, which has also given an impetus to further demand of new lifestyle and products. The local populous is motivated to seek alternative ways of life. Improved infrastructure and the resultant increase in land prices and real estate price hikes, especially in the rural areas close to the metros, have resulted in farmers selling their lands to big corporates or Government thus created a new moneyed class in these areas that otherwise would have remained backward and poor.

2. Education - with exposure to new media and increased awareness to the changes in the society a demand for higher education is seen. These tier 2 and tier 3 towns may or may not have avenues for higher education, but an awareness of the need for higher education makes parents and individuals seek it by traveling to larger cities and close interaction and association with students from larger towns again providing much needed exposure fuelling demand for multi-functional products.

3. Employment - Traveling for employment outside these towns has brought the people face to face with different perspectives and ideologies leading to changes in lifestyles thus resulting in a demand spurt and changing consumption patterns of the individual and their families. Their consumption patterns influencing the local consumption as aspiration of 'living abroad', 'earning well' and even 'to dress in similar styles' is now a common occurrence. There are several Towns in states of Kerala and Punjab in India, where each family of that town have atleast one family member settled outside the country and person sends money back home on a regular basis, thus contribute to the local economy.

4. Technology - has been a major driver that has brought about changes in consumption patterns in these towns. Exposure through social media has provided a platform for exchange of ideas and imbibing new ones. A heightened awareness of the way peers dress in other parts of the world and even in other parts of the country has created the aspirational demand for products and apparel categories for which there may be no local need or requirement.

The emerging markets in India - its tier 2 and 3 towns are seeing a surge in terms of consumption. There is a change in the consumption patterns in these towns that were looked upon as the country cousins to the urban metros. $30^{\text {th }}$ August 2012 Times of India ${ }^{13}$ stated that the rural consumption in India is growing at $19 \%$ while the urban consumption is growing at $17 \%$ only. With more money in circulation in the tier $2 \& 3$ towns and rural areas as a result of real estate transactions, changing employment patterns from being purely agricultural dependent to seeking employment in new industries that are getting established in these local areas to traveling and relocating outside for employment, has brought about social and cultural changes. Changes in state and local level governance with regional politics taking center stage have also had great impact. Brands like Hindustan Lever and ITC have used these opportunities to open new format retail outlets in tier 2 and 3 towns, which are less formidable /intimidating, and provide goods and services to these new emerging markets. These changes have been varied, unique and unprecedented bringing with them changes in demands, consumption patterns and design aesthetics.

Denim wear category is selling briskly in Tier-2 and Tier-3 towns, reaping the benefits of a growing number of customers with rising aspirations. "The aspiration levels of people are going up everywhere and so is 
their exposure to media and advertising," says J Suresh, MD and CEO, Arvind Lifestyle ${ }^{12}$ and Brands. "Brands have also taken chances and opened stores in these towns." According to Technopak ${ }^{13}$, the unbranded denim market in the overall denim business of $\$ 1290$ million in 2012. A report by the company says the denim category is expected to witness volume growth due to increased penetration in the rural geographies and smaller Indian cities and its association with 'casualization' and fashion. "This is a reflection of the aspiration to engage with fashion percolating beyond metro centric urban centres," the report states.

Exposure to new world through social media networks, television soaps, and Bollywood films are a major influence specially those that are making the tier 2 and tier 3 towns and the villages as their backdrop. The protagonists of these shows and the way the characters dress, talk, eat, and the cars and gadgets they use, all have an influence on the consumption decisions of the consumers in tier 2 and tier 3 towns. Emerging sports stars from these tier 2 and tier 3 towns have brought attention and focus to these new towns and centers and have created awareness of its population in self-belief. The two wrestling sisters from Haryana, Geeta and Ritu Phogat, have opened unimaginable opportunities to their own village and neighboring ones on sports as a career, the contribution of Dhoni from Ranchi and Pathan brothers for Baroda has been immense.

Apparel is an essential item for consumption and its choice is influenced by factors like fashion trends and social status (have arrived), demand for apparel is influenced by brands, advertisements, markets and peer groups, which tends to impact buying power of consumers. Ready-to-wear apparel is finding minimum competition from bespoke tailoring, factory shops and homemade clothing. The online presence of men's fashion outlets is growing rapidly. This study looks at these towns and rural areas and through survey and interviews aims to understand the design factors that become important while designing for the male consumers from these areas.

\section{INDIAN MENSWEAR MARKET}

The menswear market is sizeable; a 2008 report Booming Menswear market in India (King ${ }^{14}$ et al, 2008,2010 ) found that the Indian men's apparel industry was expected to grow at a CAGR (compound annual growth rate) of 14.86 percent from 2008 to 2010 . The Indian menswear market had total revenue of $\$ 11.8$ billion in 2009, representing a CAGR of 8.6 percent for the period 2005-09. In comparison the Chinese market increased with a CAGR of 5.7 percent and Japanese market declined with a compound annual rate of change of -1 percent over the same period (Vertical Edge ${ }^{15}, 2011$ ). In 2014, the Indian menswear market is forecast to have a value of $\$ 16.2$ billion, an increase of $36.1 \%$ since 2009. Clothing and Footwear Specialists is the largest segment of the menswear market in India, accounting for $89.7 \%$ of the market's total value.

The Indian Menswear Market ${ }^{16}$ report 2009 pointed to the following aspects -

- India accounts for $11 \%$ of the Asia-Pacific menswear market value

- The demand for readymade garments in rural India was forecasted to surge at a CAGR of 16.5 percent and reach Rs 42918 crore by 2010

- Branded apparel industry for men was expected to grow at 24 percent CAGR and gross over Rs 25,000 crore by 2010

- Data monitor ${ }^{17}$ report forecasts that menswear will grow at CAGR of $11 \%$ till 2020.

According to a Technopak report ${ }^{18}$ of 2012 on Indian Retail, Menswear is still single largest product category both in terms of value and volume. Men's formal suits jackets and blazer segment was valued at Rs 48.3 billion in 2009 and had witnessed a rapid shift from tailored garments to ready-to-wear.

Marketline ${ }^{19}$ report of Feb 2012 states:

- India menswear market grew by $8.1 \%$ in 2011 to reach $\$ 3.4$ billion in value

- It forecasts that in 2016 this market despite deceleration will grow by $21.4 \%$ from 2011.

According to Market report Men and Fashion: It's boomtime in men's wear ${ }^{20}$ (2010), Men's apparel a category which is used to seeing fairly high growth rates of $20 \%-40 \%$ is suddenly seeing growth of $60 \%$. The report, states that the Indian menswear market has grown 9-10 percent in year 2008-09. It forecasts that the growth will reach 40.56 percent from 2007-2012. Market value of Menswear brands is expected to reach $\$ 13.8$ billion by 2012. The report also found that "rural India, which till now completely relied upon tailored garments, has created a strong demand for ready to wear garments and was expected to grow at a CAGR of 16.5 percent by 2010 , creating huge growth opportunities". 


\section{MENSWEAR APPAREL CATEGORIES}

[1] The traditional three piece suit for men included a trouser, paired with a jacket/ coat and a waist coat worn over a shirt and under shirt (Reilly ${ }^{21}$ et al, 2008). Initially the shirt was visible only in parts; it could be seen in the collar and cuff areas (Neighbour ${ }^{22}$ 2008). Today, Upper body garments for men include shirts, which range from slim fits, classical to Big Daddy (Boswell ${ }^{12}$, 1993). Jackets range from Tailored or structured, casual, sportswear, over Coats, street wear Denim jackets to 'shakets' (a combination of shirt and jacket). The Waistcoats range from the ones that are worn as a part of the suit, photographer jackets to stylish Gillets. Twentieth century brought T-shirts as standard sportswear, concept of 'Friday Dressing' revolutionized the norms of menswear attire (Boswell $\left.{ }^{12}, 1993\right)$. Indian traditional menswear ranges from kurtas, achkans and bandgalas (Vasudev $\left.{ }^{9}, 2010\right)$. The modern menswear range includes shirts, jackets, suits, trousers, jeans and tshirts. Indian market is also becoming home to fusion wear even as it sees a huge spurt in occasion wear.

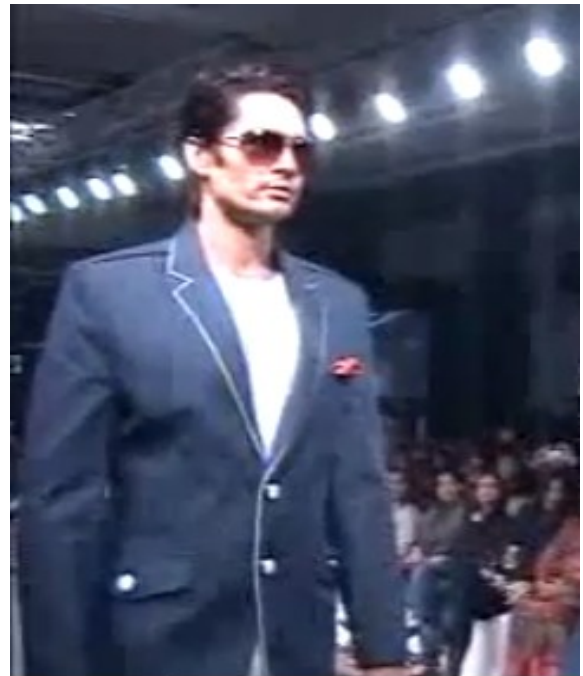

Fig 1: Garment with focus on fabric and details - Himmat Singh show Mens Fashion week Jaipur, 2012

In underdeveloped and comparatively poorer rural regions this range of options may be absent and branding irrelevant with the basic necessity of functional clothing the sole concern. Nevertheless, in more affluent areas, clothes are often perceived as intimately linked to lifestyle and social status, which grants retailers the opportunity to influence consumer behavior and drive the price range upwards. With most forms of modern media penetration by marketing icons and images, the buyer is significantly exposed to this force leading to identity creation through perception thus creating demand. Even India's conservative formal wear market is seeing a change. A study by Paul Smith, the London-based designer brand, has found that demand has shifted from simple business wear to "lifestyle", with formal wear that is more occasion-based. Occasion wear is one of the biggest apparel categories in India getting a leg-up from the Big Fat Indian Wedding, a market segment which is growing despite depression or recession by several folds.

Another interesting aspect is the changing face of the Indian consumer. The Indian consumers for this decade can be classified as (Source: Technopak ${ }^{18}$ ) -

Technology babies - 8-19yrs, Impatient aspirers - 20-25yrs, Balance seekers - 26-50yrs

In terms of consumer groups, the Indian market is now seeing a new structure with 5 consumer groups (Source: ORG-Marg) -

'The Rich', 'The Consuming Class', 'The Climber', 'The Aspirant' \& 'The Destitute.'

The largest consumer groups currently are the 'Consuming class' and the 'Climber' with nearly 75 million households in each of them. While Urban India is value driven, the Rural India at present is volume driven. General market segmentation for these emerging markets becomes difficult, as products would reflect a local taste amalgamating with other influences.

Based on these aspects of the consumer groups a survey was done on a sample chosen from population identified with the following characteristics - Male consumers from tier 2 and 3 towns / rural India, Age group 21-36, who are educated, enjoyers, brand conscious and image oriented. The sample group selected was administered a questionnaire to find the needs, preference \& actual purchases. The data collected was analyzed which gave us the design factors that need to be kept in mind while deigning for these markets and that would provide innovation and fuel business opportunities in these emerging markets. 


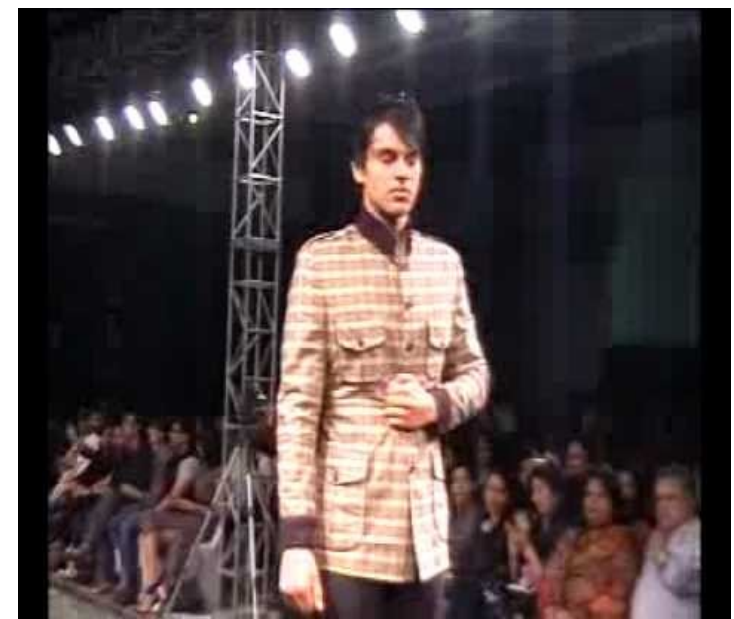

Fig 2: Pocket and pocket details in Jacket - Himmat Singh show Mens Fashion week Jaipur, 2012

The respondents were asked to prioritize the parameters kept in mind while purchasing apparel. The analysis listed these factors in the order of preference and it emerges that Fabric is the most important factor. This was corroborated in an interview with 2 designers who have a large clientele in 2 and 3 tier towns. After Fabric that is seen to be the primary factor, while making purchase decision for an outfit it was followed by Price of the outfit as second most important factor; color and details were the next two factors for deciding. Fit and craftsmanship are the least important factors while making purchase decisions. Mr. Manish Tripathi of AntarDesi, went on to add that fabric feel should be luxurious and the consumers feel that they are paying for the fabric, however craftsmanship and fit does not matter much to them. Manish, whose clientele range from Bollywood stars to politicos also has a large client base in several 2 and 3 tier towns of Punjab, Haryana, Rajasthan, Gujarat, Uttar Pradesh and TamilNadu; stated that embellishments in terms of embroidery are slowly being replaced by details like patch pockets, zippers, and color-blocking. He also said that these consumers are looking for one stop shop and want advice on accessories including shoes, watches and bags.



Fig 3: Parameters in terms of importance while purchasing Menswear

Mr. Suraj Kumar who is primarily based in Patna and has client base in Bihar, Jharkhand, UP and West Bengal also stressed on the importance of fabric and price as being the primary concern for customers. They are looking for perfect sets while making purchases. However clients in Bihar and Jharkhand are still looking for embellishments in terms of embroidery in occasion wear.
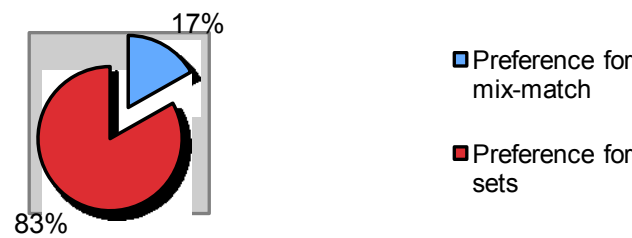

Fig 4: Purchase preferences of consumers 


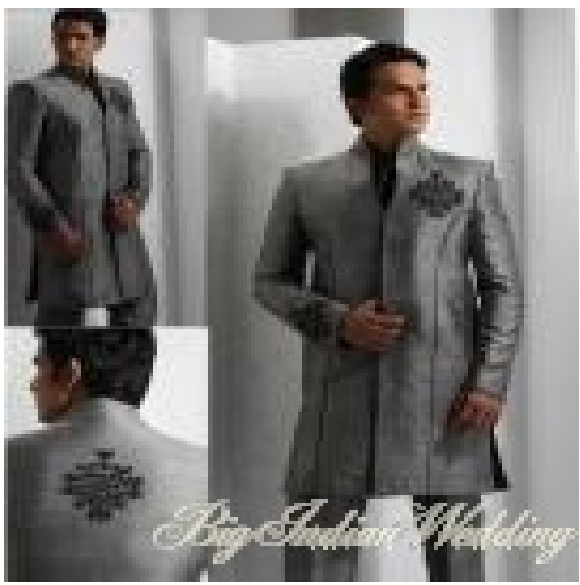

Fig 5: Occasion wear as a major purchase category

On issues of silhouette, it emerged that the consumers prefer classic styles or a combination of experimental and classic styles. Manish further added that though people want experimental, but end up picking classic styles as they do not want to look too different from the crowd.

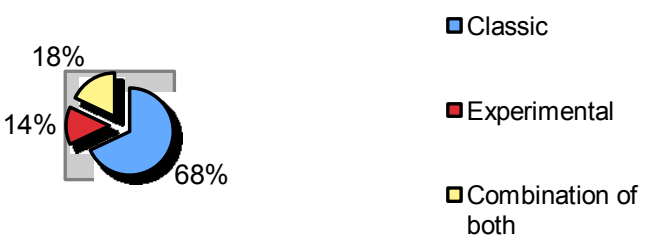

Fig 6: Preferences in terms of silhouette

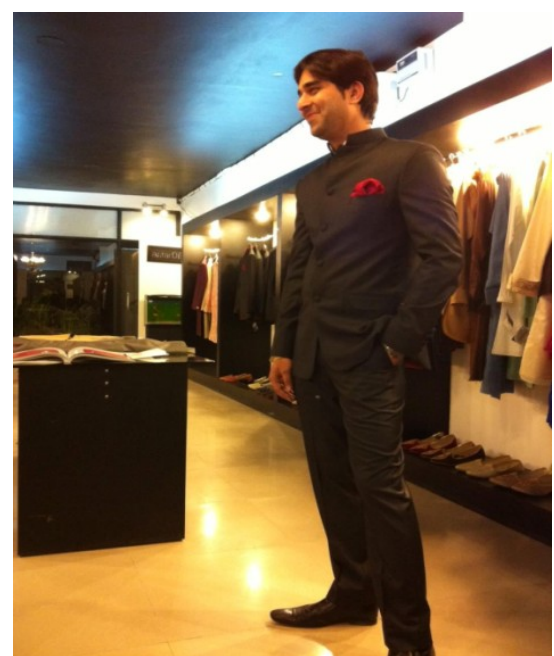

Fig 7: The classic silhouette preferred by customers

Both Mr. Suraj Kumar and Mr. Manish Tripathi confirm the findings of the survey and said that consumers are becoming conscious of both brands and designer wear and are willing to spend money on apparel especially designer wear for its aspirational value. The present day consumer in these towns is buying classic styles but is definitely looking for experimental styles.

\section{CONCLUSION}

The research shows that Indian menswear market is growing steadily and statistics show that it is expected to grow at CAGR of $11 \%$ till 2020. The rural consumption is expected to grow more than urban consumption and these markets have a different trend. Consumers of these markets are not reacting same as metropolitan consumers and to have an edge with your consumers it is important to keep price in check, to offer more than what they perceive is the right price for the product and make them feel they have got a deal. The 
consumer wants something different but does not want to stand out. The craftsmanship, fit or quality is not important to them at present, however, with growing awareness, these too shall become important. Emerging markets are uncertain yes; at the same time they offer a challenge that is very satisfying when it is won. For fashion every season in every market is uncertain and fashion thrives on this uncertainty.

\section{REFERENCES}

[1] Hopkins, J. (2011). Menswear. Lausanne: AVA Publishers

[2] Moroz, Y. (2008, May 26). Macy Reinvents Classics for Men's Closets. Retailing Today , pp. 16-17.

[3] Wehner, P. (2008, July 19). It's Reigning Men. The Estates Gazette , pp. 18-23.

[4] Marsh, E., 2008. Fast-Fashion Stored Put Focus on Men Fashion. DNR, 17 November, p. 1.

[5] Carik, J. (1994). The Face of Fashion. London and New York, NY: Routledge How to Classify Works Using ACM's Computing Classification System. http://www.acm.org/class/how to use.html.

[6] Tucker, P., 2007. Smart Fashion. The Futurist, Sep-Oct, p. 68.

[7] Anderson, L. J., Brannon, E. L., Urich, P. V., Presley, A. B., Woronka, D., Grasso, M., et al. (1999). Understanding Fitting Preferences of Female Consumers: Development of an Expert System to Enhance Accurate Sizing Selection. Nottingham: National Textile Centre.

[8] Talukdar, T. (2011, February 22). Men's Apparel Market in India was Once Larger than Women's. Retrieved March 7, 2011, from Daily News and Analysis: www.dnaindia.com

[9] Vasudev, S. (2010, September 5). Death of the Blue Shirt. Retrieved March 7, 2001, from Express India: www.expressindia.com

[10] Bakewell, C., Mitchell, V.-W., \& Rothwell, M. (2006). UK Generation Y Male Fashion Consciousness. Journal of Fashion Marketing and Management, 169-180.

[11] http://indiatoday.intoday.in/story/denim-companies-see-boom-in-small-towns-on-brand-aspirations/1/313612.

[12] Boswell, S. (1993). Menswear: Suiting the Customer. Englewood Cliffs: Regents/Prentice Hall.

[13] Technopak. (2010, November 3). Indian Apparel Market 2009. Retrieved March 7, 2011, from Images Fashion: www.imagesfashion.com

[14] King, M. (2008, February). Booming Apparel Market for Menswear in India. Retrieved March 7, 2011, from Industry reports, market statistics and community profile: www.reportlinker.com

[15] Vertical Edge. (2011, January 19). Clothing India Industry Guide. Retrieved March 7, 2011, from Articles Hub: www.articleshub.com

[16] Business Wire, 2010. Research and Markets: India Menswear Market Analysis 2010. [Online] Available at: finance.optimum.net [Accessed 7 March 2011].

[17] Datamonitor. (2010, August). Menswear: Global Industry Almanac. Retrieved March 7, 2011, from Research and Markets: 217.114.165.229

[18] Technopak, 2012. Textile and Apparel Compendium, New Delhi: Technopak

[19] Marketline, 2012. Indian Retail Scenario, New Delhi: Marketline

[20] Anon., 2010. Men and Fashion:It's boomtime in men's wear. Available at: www.fashionunited.in[Accessed 7 March 2011].

[21] Reilly, A., \& Cosbey, S. (2008). Men's Fashion Reader. New York: Fairchild Books

[22] Neighbour, M. M. (2008). The Male Fashion Bias. Queensland University of Technology. 